logos_i_ethos_2_(33)_2012, s. 263-270

Lucyna Skraba

\title{
Hermeneutyczne aspekty humanistyki
}

\section{Michał Januszkiewicz, Kim jestem ja, kim jesteś ty? \\ Etyka, tożsamość, rozumienie, Wydawnictwo Poznańskie, Poznań 2012, ss. 288.}

Wydana w ostatnim czasie przez Wydawnictwo Poznańskie, na wskroś interdyscyplinarna, książka Michała Januszkiewicza jest kolejną publikacją, któ-

Lucyna Skraba - doktorantka w Katedrze Etyki Wydziału Filozoficznego Uniwersytetu Papieskiego Jana Pawła II w Krakowie. Interesuje się hermeneutyką, etyką, teorią literatury, antropologią kultury.

rej mniej lub bardziej wprost wyartykułowanym zadaniem jest przybliżenie polskiemu czytelnikowi problematyki związanej z hermeneutyką i oddziaływaniem jej na inne, określane jako humanistyczne, dyscypliny. Jest ona próbą odpowiedzi na w gruncie rzeczy kantowskie pytanie dotyczące naszej egzystencji - Kim jest człowiek? Pytanie to nieuchronnie przywołuje kolejne: Co mogę wiedzieć? Co powinienem czynić? Czego się mogę spodziewać?, które w różny sposób modyfikowane wydają się z większą lub mniejszą siłą, głośniej lub ciszej rozbrzmiewać nie tylko w recenzowanej książce, ale także na współczesnych dziedzińcach pogan. Intrygujący i przykuwający uwagę tytuł książki - będący na swój sposób dla współczesnego człowieka przecież pytaniem prowokacyjnym - daje potencjalnemu czytelnikowi nadzieję na uzyskanie nań odpowiedzi. Tytuł jest nawiązaniem do tytułu jednego z tekstów Hansa-Georga Gadamera, o czym we Wstępie informuje autor - poznański naukowiec, pracownik Instytutu Filologii Polskiej Uniwersytetu Adama Mickiewicza. Poszukuje on odpowiedzi na tak postawione pytanie, odwołując się do dorobku różnych myślicieli związanych z bardzo szeroko rozumianą hermeneutyką, stanowiącą - o czym możemy się przekonać, analizując do- 
robek naukowy Januszkiewicza - od wielu lat jego pole badawcze. Książka, której pełny tytuł brzmi: Kim jestem ja, kim jesteś ty? Etyka, tożsamość, rozumienie, składa się z XV rozdziałów, przyporządkowanych (odnosi się w trakcie lektury wrażenie, że arbitralnie) do jednej z trzech części: W stronę hermeneutyki, W stronę antropologii i religii, Tożsamość i etyka, na które została podzielona publikacja. Niektóre z tekstów - takie informacje możemy znaleźć w Nocie edytorskiej - znane są czytelnikom z innych publikacji. Patrząc z perspektywy czytelnika, który niekoniecznie może mieć wiedzę na temat hermeneutyki, niezwykle ważny dla rozumienia i ukierunkowania interpretacji całej, w sumie obszernej i wewnętrznie zróżnicowanej, publikacji jest wspomniany wyżej Wstęp, który mógłby stanowić osobny rozdział książki. Autor tłumaczy w nim zarówno tytuł swojej książki, której problematyka hermeneutyczna rozwijana jest w horyzontach etyki, tożsamości i rozumienia (zob. s. 9), mimo że wewnętrznego podziału na owe części dokonuje, jak się zdaje, według innego kryterium. We Wstępie przywołuje najważniejsze założenia filozofii Heideggera, Gadamera czy Ricoeura, których niezwykle istotny wpływ na oblicze współczesnej (również ponowoczesnej) hermeneutyki trudno zakwestionować. Januszkiewicz formułuje na początku niezwykle interesującą tezę mówiącą, że „charakter nowoczesnej i późnonowoczesnej hermeneutyki przyjmuje postać trójkąta hermeneutycznego, na który składają się trzy wymienione problemy" (tamże), zaś związki i zależności między bokami, którego podstawą jest rozumienie, dostrzega w filozofii wspomnianych myślicieli. Dodaje dalej, iż:

Metafora trójkąta hermeneutycznego pokazuje zarazem uniwersalność problemu hermeneutycznego, który opisywać możemy na gruncie trzech fundamentalnych zwrotów w humanistyce nowoczesnej: zwrotu lingwistycznego (jeżeli przyjąć za Gadamerem, że rozumienie dokonuje się w horyzoncie tego, co językowe), zwrotu etycznego i zwrotu narratywistycznego (tożsamość). Innymi słowy: współczesna humanistyka okazuje się nieuchronnie hermeneutyką (s. 9-10).

Wymienieni myśliciele nie są oczywiście jedynymi, których refleksja filozoficzna czy też literaturoznawcza (autor wielokrotnie odnosi się do 
wyników badań Michała P. Markowskiego) jest przywoływana na kolejnych kartach książki. Oprócz wspomnianych filozofów, innymi, do których w taki czy inny sposób odwołuje się autor w swojej książce, są: Platon, F. D. Schleiermacher, W. Dilthey, F. Nietzsche, J. Derrida, J. D. Caputo, R. Rorty czy G. Vattimo. Przyjrzyjmy się więc kolejno rozdziałom, których adresatami naprzemiennie będę zarówno filozofowie, może nie tylko ci zainteresowani hermeneutyką, kulturoznawcy, jak i wszyscy ci, którzy chcą dotrzeć do sensu, który skrywa literatura.

Pierwszą część książki rozpoczyna opublikowany kilka lat temu na łamach miesięcznika "Znak” artykuł Czy mamy dziś kryzys humanistyki?. Tekst, jak się wydaje, w dalszym ciągu aktualny i domagający się odpowiedzi na postawione w tytule pytanie. Autor zastanawia się w nim nad wymiarami tego kryzysu, skupiając się przede wszystkim w swoich analizach na perspektywie teoretycznej i wskazując za Rortym na literacki wymiar humanistyki. Rozważaniom tym towarzyszą uwagi dotyczące treści książki J. M. Elliasa Literature Lost: Social Agendas and Corruption of the Humanistes, w której amerykański teoretyk literatury krytykuje ponowoczesną i zorientowaną literaturoznawczo humanistykę. Januszkiewicz przypomina współczesnemu człowiekowi, że „tylko humanistyka potrafi podjąć debatę nad pytaniami zasadniczymi: Kim jesteśmy? Co mamy począć z naszym życiem? Czy istnieją granice ludzkiej ingerencji w świat natury?" (s. 25). Humanistyka jest, jak się okazuje, niezbędna, ponieważ - jak dodaje dalej poznański teoretyk literatury - „z jednej strony przeciwstawia się panowaniu techniki, z drugiej - pragnie nadawać jej humanistyczny wymiar" (s. 26). Wielość i różnorodność teorii, narracji i języków, odejście od tego, co pewne i jednoznaczne, a co charakteryzuje ponowoczesną rzeczywistość, nie jest dla autora wyznacznikiem kryzysu, lecz raczej szansą, aby człowiek wrzucony w-bycie spróbował siebie i świat zrozumieć, a tym działaniom będzie towarzyszyło nieustanne poszukiwanie sensu. W kolejnym rozdziale zatytułowanym Hermes tłumacz i Hermes krętacz albo: między rozumieniem a nie-rozumieniem w bardzo przejrzysty, i może dla niektórych zbyt uproszczony sposób, pokazana jest droga, jaką przeszła hermeneutyka od oświecenia do czasów współczesnych. Przeprowadzonym analizom przyświeca 
nadrzędny cel, jakim jest pokazanie napięcia między rozumieniem a nie-rozumieniem. Januszkiewicz wyodrębnia więc trzy następujące po sobie „przygody” hermeneutyczne, z których każda w inny sposób podchodzi do problemu rozumienia, ale także do tradycji. Przyjmując takie kryterium podziału, rozróżnia hermeneutykę (przygodę) tradycyjną, w której rozumienie jest pełne (oświecenie) i niecałkowite (romantyzm), nowoczesną, zakładającą, że rozumienie jest trudne, zapośredniczone przez język, oraz ponowoczesną (radykalną), głoszącą, że rozumienie nie jest możliwe, ze wszystkimi tego konsekwencjami.

Dalsze rozdziały: Nauki o kulturze a hermeneutyka, Hermeneutyka jako miejsce spotkania filozofii $i$ literatury, Prawda $i$ literatura, Wolność $i$ interpretacja, Wczytywanie (się) $w$ tekst. O interpretacji transakcyjnej, w interesujący sposób pokazują nie dla wszystkich oczywiste, ale nader ważne związki między literaturą - kulturą a filozofią. Uświadomienie ich sobie, o czym skutecznie przypomina i w czym pomaga Januszkiewicz, pozwala $z$ innej strony spojrzeć na kulturę, próbować ją zrozumieć i dotrzeć do jej sensu. Nie możemy zapominać, że refleksja filozoficzna jako specyficzny wytwór działania człowieka również należy do kultury. Tylko wejście z nią w dialog, stawianie pytań i wsłuchiwanie się w odpowiedzi, których udziela (a więc przyjęcie postawy hermeneutycznej), jest daniem sobie szansy na rozumienie innego (Ty) i samorozumienie siebie. Autor komentując wielokrotnie przywoływanego w publikacji Heideggera i jego ontologię bycia, stwierdza, że:

Rozumienie określone jest więc zawsze poprzez uczestnictwo w kulturze i w tym, co historyczne (to, co zmienne, nigdy nie dane raz na zawsze. Podlegające nieustannej reinterpretacji). Ten, kto rozumie, a kogo nazwałbym teraz podmiotem kulturowym, rozumie zawsze na gruncie określonej sytuacji, rozmaitych ról społecznych, obszarów zainteresowań, wartości, potrzeb i celów (s. 59).

Akcentuje w ten sposób, że bycie jest byciem-w-świecie, który jest nieuchronnie światem kultury, domagającym się rozumienia i interpretacji. 
Lektura tekstów składających się na najobszerniejszą, bo stanowiącą właściwie połowę książki pierwszą część, daje czytelnikowi do zrozumienia, że „efekt” interpretacji będzie uzależniony od otwarcia na głos tekstu, a co za tym idzie, od zauważenia ograniczeń paradygmatycznych, wynikających z przyjęcia określonej koncepcji znaczenia, a także wynikających z przyjęcia odpowiedniej koncepcji prawdy. Autor charakteryzuje także trzy linie interpretacyjne: dekonstrukcyjną, hermeneutyczną (hermeneutyka radykalna) oraz pragmatystyczno-konstruktywistyczną. Omawiając linie interpretacyjne zwraca uwagę na fakt, że „problematyka wolności interpretacji nie jest w jednak w stanie obyć się bez ograniczeń” (s. 140). Jednakże, jak dodaje:

ograniczenia stawiane na gruncie dekonstrukcji, hermeneutyki radykalnej, neopragmatyzmu i konstruktywizmu, przybierają zdecydowanie odmienny charakter niż w nurtach, które usiłują narzucić postawy uwikłane w wyraźne postawy metafizyczne (tamże).

Drugą część książki otwiera artykuł Bachtinowska antropologia słowa i jej implikacje dla humanistyki, poświęcony rosyjskiemu filozofowi znanemu czytelnikom przede wszystkim jako komentator i interpretator twórczości Fiodora Dostojewskiego. Refleksje Michaiła Bachtina dotyczące słowa, będącego domeną tego, co polifoniczne, dwugłosowe, dialogowe, zestawione zostają z rozważaniami na ten temat wyeksplikowanymi w literaturze filozoficznej Gadamera. Takie interesujące zestawienie ze sobą dwóch - jak się okazuje, niezbyt odległych - koncepcji (z jednej strony Bachtina, $z$ drugiej Gadamera) i wskazanie podobnego rozumienia wielu kwestii związanych z językiem może być, zarówno dla filozofów, jak i literaturoznawców, pretekstem do przeprowadzenia głębszych badań w tym zakresie. Szkoda jednakże, że autor nie odniósł się w swoim tekście do publikacji zawartych w II tomie antologii Ja - inny. Wokół Bachtina, wydanej pod redakcją Danuty Ulickiej (Kraków 2009), które pokazałyby aspekty twórczości krytycznej Bachtina z innej perspektywy.

Następne dwa rozdziały w części drugiej książki Januszkiewicza koncentrują się na omówieniu filozofii Heideggera z zaakcentowaniem 
stosunku autora Bycia i czasu do antropologii (Heidegger i antropologia), a także refleksji dotyczącej zwrotu religijnego w hermeneutyce ponowoczesnej (Śmierć śmierci Boga). Tematem rozważań związanych z namysłem nad religią, doświadczeniem religii i wiary, są kolejno głosy filozofów utożsamianych z hermeneutyką, jak: John D. Caputo, Gianni Vattimo, Richard Rorty, Jean-Luc Marion oraz Richard Kearney. Podjęty temat i przeanalizowany właśnie od tej strony zasługuje na uwagę, ponieważ - jak podsumowuje autor - „ponowoczesna hermeneutyka w jej licznych zróżnicowaniach odgrywa obecnie szczególną rolę w dyskusjach, które na nowo rozgorzały w ostatnich latach wokół doświadczenia religijnego" (s. 210).

Na osobne zainteresowanie czytelników zasługuje też ostatnia część książki, którą otwiera tekst Zwrot etyczny w nauce o literaturze, który - jak się wydaje - powinien być nie tylko lekturą osób zajmujących się etyką. Wspomniany tekst, ale również pozostałe, dotyczące pisarstwa Hermanna Hessego, a powstałe w pierwszej połowie pierwszego dziesięciolecia XXI wieku, przede wszystkim powinny zwrócić na siebie uwagę tych, którzy bardziej lub mniej zawodowo zajmują się interpretacją nie tyle tekstów literackich, co - chciałoby się rzec - tekstów kultury. Autor ostatnią część rozpoczyna od artykułu analizującego rolę etycznego zwrotu w nauce o literaturze, odgrywającego istotną rolę w czytaniu (interpretacji), która ,jawi się jako akt etyczny, o ile okazuje się inwencją, wytwarzaniem nowych języków lektury, które zachowują czytany tekst przy życiu, stanowią (...) formę mówienia czytanemu testowi «tak», są jego afirmacją" (s. 224). Tę część książki uzupełniają cztery artykuły (Między „logos” $i$ „mythos”. O pisarstwie Hermanna Hessego, Między upadkiem a reintegracja (Hermanna Hessego proza o dojrzałości), Wokół etyki autentyczności, „Wilk stepowy” - powieść o lęku $i$ wyobcowaniu) będące - zgodnie z zamierzeniem autora - pokazaniem hermeneutyki w działaniu i zastosowanie w konkretnym, zmierzającym do interpretacji, spotkaniu z tekstem.

Selektywne i siłą rzeczy pobieżne zaprezentowanie problematyki najnowszej publikacji Michała Januszkiewicza sprawiło, że część - zapewne istotnych $\mathrm{z}$ innego punktu widzenia - zagadnień poru- 
szonych w książce nie zostało zasygnalizowanych. Wielość i różnorodność tematów zanalizowanych w poszczególnych tekstach zawartych w recenzowanej pracy, których problematyka koncentruje się wokół pojęć: etyka, tożsamość, ale przede wszystkim rozumienie, będzie dla wielu czytelników okazją do zweryfikowania swojej wiedzy na temat hermeneutyki i humanistyki. Niewątpliwie wielką zaletą książki jest język i sposób narracji. Nie koncentrują na sobie uwagi czytelnika, dzięki czemu pozwalają mu skupić się na rozpatrywanym zagadnieniu, do którego powinien się odnieść niekoniecznie aprobująco. Książka jest jednym z wielu głosów, mającym wyeksplikować, co się kryje za pojęciem „hermeneutyka”, jaka jest jej rola w filozofii, kulturze, literaturze. Mimo że stanowi pewną spójną całość, można, czy wręcz należy, poszczególne rozdziały czytać i analizować jako odrębne teksty, których zrozumienie nie będzie wymagało znajomości treści pozostałych zamieszczonych w tomie. Może w tym przeszkadzać sposób zredagowania przypisów (ciągłość numeracji w obrębie danej części książki, a nie w obrębie rozdziałów; w części pierwszej jest ich 300!), co przy braku na końcu książki zestawienia bibliograficznego wykorzystanej literatury może być dla czytelnika irytujące. Dużym redakcyjnym niedopatrzeniem (?) jest brak informacji na temat zamieszczonego na okładce książki obrazu, który jest pracą René Magritte’a Kochankowie, a nie, jak sugerowałaby to informacja wewnątrz książki, dziełem osoby, która projektowała okładkę. Umieszczenie tego obrazu na okładce książki jest skądinąd bardzo interesującym pomysłem, bo prowokuje jej czytelnika do podjęcia działań zmierzających do interpretacji obrazu. Pozostaje mieć nadzieję, że dialog, bo tym jest przecież czytanie, z tekstami Michała Januszkiewiecza w konsekwencji sprawi, że czytelnik sięgnie po teksty źródłowe związane z szeroko rozumianą hermeneutyką, która, jak się zapewne przekona, mieni się różnymi kolorami. W ostatnich partiach książki autor tak ją definiuje:

Hermeneutyka nie jest metodą czy nawet pomysłem na czytanie tekstów. Nie jest też po prostu specjalnością, przedmiotem znawstwa, dyscypliną. To coś znacznie więcej: pewien typ wrażliwości, a raczej całościowy sposób bycia, 
którego charakter wyznacza nieustannie ponawiana próba podejmowania rozumienia świata, w który zostaliśmy wrzuceni, i który musimy jakoś oswajać. Hermeneutyka to próba rozumienia togo, co właściwie się dzieje, co się przydarza. To nieustanna próba podejmowania rozmowy, w której nie pada nigdy ostatnie słowo. Bo choć celem rozmowy jawi się porozumienie, to jednak Inny (człowiek, świat, tekst) zrozumieć się do końca nie da: Individuum est ineffabile (s. 278).

Pojęcie „wrzucenia” sugeruje Heideggerowskie wrzucenie w bycie albo Gadamerowskie wrzucenie w tradycję i język. Natomiast zwrot „rozmowy, w której nie pada nigdy ostatnie słowo” pochodzi od Gadamera.

Czy to jest jakaś odpowiedź na pytanie postawione w tytule książki Kim jestem ja, kim jesteś ty? Może. Jednakże jaka ona będzie, czy i jak ją sformułujemy, zależy od nas samych. Książka Michała Januszkiewicza może zapewne stać się jednym $\mathrm{z}$ wielu przewodników w tych poszukiwaniach. 